\title{
A Comparative Study of Natural Sciences as a Miracle and Natural Laws: A Case of Historical Linguistics
}

\author{
Farajollah Barati ${ }^{1}$, Amir Divani ${ }^{1}$, Mohsen Javadi ${ }^{1}$, Amir Abbas Ali Zamani ${ }^{1}$ \\ ${ }^{1}$ Department of Comparative Philosophy, Science and Research Branch, Islamic Azad University, Tehran, \\ Iran
}

\section{ABSTRACT}

This study investigated the comparison of instructing natural sciences as a miracle and natural laws through the comparative linguistic process from Eastern and Western scholars' perspectives. This study may provide some evidence on the problems the teachers face in designing a new method of using cause and effect processes speaking skills. This may help the English language learners to follow these processes in speaking and class discussions in a comparative study of Western and Eastern approaches to class discussion. The method of this study was based on historical design. The participants filled in a researcher-made questionnaire to compare their views on the two major schools of Eastern and Western thoughts referring to the schools' contributions to teach causality. Data were analyzed and the results showed that both schools have relied on their background perspectives on religious thoughts. Therefore, the main findings of this study focuses on the compromise of East and West to make a unique method in instructing cause and effect processes.

KEYWORDS: Comparative linguistics; Natural Sciences; Cause and Effect process; Miracle and Natural Laws.

\section{Council for Innovative Research}

Peer Review Research Publishing System

Journal: Journal of Advances in Linguistics

Vol 2, No. 2

editor@cirworld.com

www.cirworld.com, member.cirworld.com 


\section{INTRODUCTION}

Teaching cause and effect processes to learners who are enrolled in speaking skill classroom could be very demanding since the need to know how to discuss causes of the effects happened in the nature. Teachers of such classes need to manage students with different ethnicity and cultural background in multicultural classes to arrive at negotiation of meaning (Stiver, 1996). Thus teachers need to have precise ideas on views of Eastern and Western philosophers and the relationship between miracles and laws of nature regarding cause and effect processes. Effects depend on the laws that have been raised in either in empirical or philosophical sciences.

Miracle is defined as doing an act from God, the prophets or saints in a natural way. In other words, there is no magic in conducting the miracle. We may call them metaphysics. They could not be justified by human beings as a normal process in nature. The causes could be super natural and cannot be done by ordinary people. Laws of nature such as theories of physics, chemistry, natural happenings may be named as the physical events which could be done by any expert. They are universal, frequent and dominated the world.

However, Suine Burne (1989) emphasizes on the concept of violation of nature by miracle in the West. According to this point of view, if a miracle is more amazing, it can be considered to be more the action of God. If a miracle is not repeated we can conclude that it is not following the law of nature. If we look at this issue from the quantum point of view, it is not clear what should be considered as contradiction or violation of natural laws. Because distinguishing the contradictory or exception in general law is easy. However, statistical laws do not reject the contradictory cases. Since what we may eliminate now may be confirmed later. Moreover, the nomination of the necessity of the laws of nature to natural causes did not mean that these laws are unacceptable ; since there are a series of laws and supernatural causes in the world that have the power of impression on laws of nature so cease them. Besides, the whole natural and supernatural laws underlay the divine providence. Most of god believers argue that the order of world is under the rules and laws. To be illustrated answer to this question that is miracle violated the laws of nature, according to the rules that dominated the world, and the problem of miracle in the light of empirical and scientific point of views; and philosophical demonstration, and the theories of philosophers of religion, both Islamic and western.

\section{REVIEW OF LITERATURE}

\section{Comparative Linguistics of Western and Eastern School of Thoughts}

There are three general approaches (Plantinga, 1993) stated by Western thinkers about miracle and nature's laws of Christianity about violating law of nature in miracle proposed in the Holy Bible. According to the texts of the Holy Bible, there are several narratives that have been attributed to Jesus that he is healer of sick people, giver of sight to blind people, giver of hearing to deaf persons and reviver of dead bodies. Accordingly, the statements and other discussions that are expressive of Christianity's look at the miracle referring to miracles as constitutive of orthodox belief and they believe that God impresses material world regarding to his heavenly power and his heavenly nature is in a way that his manifestations on earth create such extraordinary events. This is as in historical Christianity, the embodiment of God in world is known as the most eminent miracle in human history that has reached to its climax in the event of hanging Christ and his revival. The quoted miracles of New Testament as the guidelines and signs of God's influence on natural world and ordinary discipline; however, it doubted about the accuracy and originality of most of historical miracles to some extent.

Interpretation of world based on materialistic viewpoint that its offset has started since ancient and developed Greece by Aristotle that reached to its climax in seventeenth and eighteenth centuries under the title of materialism which based on it they know the world recognizable only by concrete senses and in nineteenth and twentieth century, it has affected all majors of science in west that until today it is dominating on western thought, philosophical materialism which has been inspired from this theory considers not only miracles but also every kind of relation with an aspect of reality except physical reality as irrational and arisen from fancy or ignorance or weakness of natural causes ' researches. Some believers of this view point who considers every phenomenon interpretable in general frame of nature's laws claim that about miraculous events we cannot be sure that nature's law has virtually been violated in this especial case and by attending to this point of view, some of religious philosophers defend from proving miracles as violation of natural laws.

According to new scientific opinions and developments which are done in modern science and which are versus to philosophical materialism, this modern opinions have emerged since twentieth century and by studies about fracture of atom and the principles of Heisenberg and relativity theory of Einstein in relation to this issue. Werner Heisenberg believes that human beings are living in a widespread world. Abstract concepts and phrases which describe soul and God own more accordance with reality to the very developed phrases and concept of physics. In this respect, analyzing and describing scientific theories written by William James (Pawelski, 2007), an American philosopher and psychologist who was also trained as a physician and viewpoints of Sigmund Freud (Dilman, 1983, 1984) and theories of other scientists that signed to spiritual phenomena like "supersensible senses", "open-mindedness", "survival and experiments of deed's".

Saint Augustine (Peterson \& Randall Niles, NavPress, 2007) says: In our mind, it seems that miracle is happened in the opposite direction of nature's order but God who has created; he doesn't consider it versus to nature's discipline. Nature always remains in the way as God wants it to be whenever we assume something opposite to nature we have gone to the false way. Is it possible that something happens based on God's will and wish of creator is the nature of every creature; therefore miracles are not contrary to nature but are contrary to ordinary and common order that we have understood from the beginning. 
The common mood of western thinkers' outlook about this issue is that they consider miracle contrary to nature's system that is engendered exceptionally by the intervention of a supernatural element. Regarding to this definition of miracle, Thomas Aquinas says that generally, miracle is attributed to the events that are realized beyond natural order and by means of God and it should be defined as: violation of one nature's law by especial will of God or by a sightless element.

Eminent Christian thinkers of medieval centuries that their most outstanding one was St. Thomas Aquinas (Baglow, 2005) had such a belief about nature Aquinas reminded this point that God has established the natural cause and effect order in objects. Normal causes and factors mainly act bused on this natural discipline equally and the same; however some when they stopped from a normal and steady process of not existing suitable conditions or because of an obstacle and then it leads to create an abnormal and rare phenomenon like burning an infant with six fingers of hand. In order to involve God's determination in world's affairs, Aquinas and a great number of speakers believed to the "obedience strength" in the essence and substance of nature as this existing strength in nature of creature causes creature to act based on God's determination.

Aquinas thinks that the existing natural order in objects is arisen from the freewill of God not because of natural necessity of substance. Besides, he believes to another order which is beyond of natural order that is arisen from God's knowledge and will and on this basis, they believed to miracles and found them beyond natural discipline and generic divine order as God performs affairs that are possible according to natural order by his will because they are possible according to natural order by his will because they are possible for him, therefore in their mind, miracle is impossible based on nature and dominant order but whereas nature is the creature of God and is under his free determination, God can violate it by a law which is beyond the existing laws of nature. He expresses: "Now, if we attend to the order of affairs from this aspect that they are subsidiary of the first cause, God cannot do any affair contrary to this order; that if he does such an action, he performed an action contrary to previous knowledge and his will and determination, but if we consider object's order from this aspect that they are subordinate of second cause not the first cause, the God can perform actions beyond the mentioned order, because he is not follower of second cause order, but on the contrary, that order follows him ; because this order has been sent out by him, and not because of natural necessity but based on God's free will; since God could create another kind of order and discipline. Thus, if God wishes, he can create effects without considering Second action or to create definite effects that they are effect less on second causes and here St. A Gustine says: "God performs actions contrary to the first and principal order; then he does not act contrary to himself'.

Thomas Aquinas believes that miracle is done by a hidden cause that is God since his reality and nature is latent from others, us a result miracle is odd and amazing to all, He believes that difference of miracle with other rare affairs that are un normal and happen some when and arouse the amazement of people who are not aware of it; is hidden in this point that these kinds of events have a cause in the nature of objects but is hidden and mysterious to a number of people, because we cannot never find a recognizable reason for miracle and such a perfectly hidden reason by intellect. Some of other Christian thinkers (Moser, 2010) believe that miracle goes only beyond natural tangible and material ability not beyond all natural tangible and material ability not beyond all natures of objects. Based on this outlook, angels and confirmed humans by God by owning the power arisen from divine diffusion and spiritual endowment can be the supernatural factor of miracle.

Since seventeenth century later on, Christian thinkers interpreted objects based on natural laws that are placed instead of natures, events essentially happen after and following the other event. Nature's laws can be superficially comprehensive and statistical general laws are as this that something is essentially what is it or causes to create another thing. For instance "A" is essentially "B" or causes to create it that is expressive of universality and necessity and doesn't accept exception but statistical laws express that something happens base on a definite amount of possibility. The paradigm instances of canon are triple laws of new ton about general movement and gravity law. Above laws express that how objects with different volumes have discipline and primary definite velocity that take advantage of other orders and definite velocities. According to Tabatabai (1973a, 1973b, 1993, 1995), an Iranian philosopher, miracles is not a violation of the principle of causality or laws of nature, but as they are kinds of a restriction of a law by another law. God is able to create the same thing through many different meditation or natural instruments. Every event that happens in the universe is necessarily documented by natural causes and natural causes such as usual causes and unusual causes and extraordinary events such as miracles are documented to natural unusual causes. In addition to these two causes, there are real causes of other intermediaries. The true intermediaries in addition to being natural and material they have remained Unknown and unattainable despite of developments of technology. God has determined a direction for events to be happened and has related that events with other creatures and phenomena. Though, the apparent causes are not related to these events or phenomena, these connections and relations to extra ordinaries are applies in such a way that what he wishes will happen.

In short, regarding to this issue that what interpretations the concepts of violating habit, nature's law, natural causes and factors have what interpretation, they are effective in answering this question that if miracle is violation of nature's law. Thus events that are not interpretable by experimental sciences under the title of natural causes and factors dominant on phenomena if they do not violate nature's laws, such events are not forbidden, thus miracle is not essentially violator of nature's laws. While according to the experimental outlook, the events which are discovered opposite to natural causes and elements are counted as violators of nature's law. Accordingly, miracle is a violation of nature's law, it encounters to a controversial conception and we have confirmed that despite of the fact that miracle is subsidiary to nature's system but has violated this natural order exceptionally. Now this question is imposed that how is it possible that some natural laws governing on world's phenomena that are unchangeable and from the other side, for some cases like miracle these unchangeable laws change and this is a paradox, because a law which is violated cannot called as law and a rule or order which can be violated, then we cannot know it as a natural law. Because it means that a law is not really law or an event 
"miracle" which has violated law cannot occur in other words, this is like we say what has happened is not miracle and what is miracle cannot never occur.

\section{METHOD}

\section{Corpus}

The data were collected through the library sources among the Western scholars (e.g., Karnap, 1974; Welfson, 1979; Hasperz, 1982; Hick,1983; Kapelson,1986; Watson,1987, Kovari, 1989; Baglow, 2005; among others) and the Eastern ones (e.g., Ibn Sina, 1403; Ibn Meimoon, 1914; Ibn Arabi, 1921; Ibn Roshd,1965; Ashtiyani \& Seyed Jalalaldin, 1989; Ebrahimi Daniani, 1991; Javadi Amoli, 1991; Ibn Roshd \& Ibn Mohammad,1992; Ibn Khaldoon, 1995; Amedi, 2012; among others). The their ideas and beliefs concerned with instructing natural sciences as a miracle and natural laws were reviewed to find any similarity and differences in terms of cause and effect process to argue or discuss opinions in speaking classrooms. Abstracts of both schools of thoughts were matched by the researchers to form a questionnaire included 32 items extracted from theoretical issues and abstract thoughts proposed by Western and Eastern scholars. These ideas made the formation of the research questionnaire.

\section{Instrumentation}

Questionnaire of comparative study on the influence of Western and Eastern scholars' perspective on influential class discussion on cause and effect processes in speaking classes included 32 items. The face validity and reliability of the questionnaire were met in a pilot study. The reason that we trust on both Western and Eastern ideas are not only due to an essential relation between both schools of thoughts but the reality which is arisen from the observation of correctness of these events through an agreement of real affairs with the report of real vouchers.

\section{Procedure}

More than one hundred library sources were studied and examined to form the questionnaire extracted from theoretical issues and abstract thoughts proposed by Western and Eastern scholars. The main issues included: (1) experiment is our only guidance about deduction in real affairs and is the final reference for solving all disputes and we can distinguish realities from assumptions with experiment; (2) a wise person has reason and harmonizes his belief with reason, thus whatever the subject distances needs a more reliable reason and we should step on the certainty roof by the ladder of reason. This requirement doubles when it is contrary to nature's law. Since in this state, we encounter to inevitable paradox of two experiments and then opposite and adverse experiments are compared to each other and the preferred experiment is chosen with doubt; and (3) our trust to the report of evident is an experimental principle. These ideas made the formation of the research questionnaire. Data were collected through the administration of 100 copies of the questionnaires among the university students who were at M.A level and enrolled in Theology courses in fall semester 2013. Chi-square analysis was run to analyze data.

\section{RESULTS}

Results showed that there is not a significant difference between the participants' views on the inflectional role of Western and Eastern schools of thoughts in discussing miracle and other abstract issues in Theology classes. They believe that both schools can form a compromise in dealing with cause and effect arguments. Observed Chi-square was $\left(X^{2}=2.852\right)$ which is less than the critical Chi-square as $\left(X^{2}=3.18\right)$. Results showed that the participants have focused on the relationships between the Western and Eastern thoughts to provide shared knowledge of physics and metaphysics in speaking classes. Thus, if miracle is defined as violation of nature's law, this fault is found that miracle is a self-paradoxical concept but based on the interpretation that Islamic philosophers and speakers have that miracle has the possibility to occur intellectually. The outlook of believers of miracle's conflict with nature's laws have been analyzed and examined that following issues are from doubts that have been criticized: (1) claim without reason: opponents have not clarified that how miracle has conflict with nature's laws. By assuming that violation habit is impossible and considering this assumption certain as a principle, they believe to paradox provided that believers of this outlook should express that whether the transformation of violation habit by the command of wisdom is necessary and obvious or is it a theoretical judgment? And then if they know it as assembly violation of paradoxes, it means that if they consider violation of habit obvious and impossible and all scholars of major of them confirm it, but this is not true and if they know it as theoretical command, then its impossibility needs representing reasonable cause, but believers used generalization technique for this relation; and (2) natural and usual transformation: what scholars judge as transformation in the first stage is usual transformation, like hearing sound or observing image from very long distances that was completely impossible for people belonging to several centuries ago. They also doubted its possibility but it does not mean natural and intellectual transformation, thus by passing time and developing human beings' sciences, they could actualized it that the progress of communicational sciences like telephone, television, fax and internet are the best instances of this claim, however activities related to violations of habit and miracles are beyond the capability of others, but lacking the power of doing an action is not the reason on its natural metamorphosis, since the presenter of an unusual action has a kind of feature and characteristic which produces power for doing that extraordinary action.

\section{DISCUSSION}

Hume's (1969) deduction about violation of nature's law by miracle could be justified as he argues that the relation between an incident and law of nature differs from the relation of a human with government's law. Because of this reason, 
if a person violates government's law, frequently we do not say that law has done a wrong action but we say the person is guilty, but about an event that reveals untruth of a law and we say that event is false, we said nonsense as if we say nature's law has been violated in this case. Nothing can be presumed as violation of law of nature and if the response of the question that what is miracle is such as this, we should say that such a thing cannot exist as miracle.

All claims about this issue that what is nature's law are reform able. Every claimed law may some day is proved that it's not a true law, however it owns much validity. There upon, all claims about that violates laws of nature or does not violate it, will be in this way when an event apparently violates such a law, this phenomenon may occur simply because only true law that could interpret that event did not enter to the mind of any one or they have contemplated about it, but it is complicated to the extent that should put it aside before examination or it's too complex to accept it without more test and tests are practically too difficult to perform. Perhaps after wards, new scientific information will be gained to force us to change our mind in such claims about natural world are reform able and we should achieve to temporary results based on available evidences.

We have some reliable evidence (Moser, 2010) about this subject that what are nature's laws and some of nature's laws have completely been proved and are expressive of much data that every reformation we suggest about them in order to justify one counter- instance would be adhere that it over turns whole structure of science. In such instances, there are reliable and valid instances on that if one counter-instance happens, it was violation of following events happened, there were violation of laws: flight, rising from grave with perfect health about a man whose heart had stopped for 24 hours and was dead; changing water to wine without help of a system or chemical catalyzers; healing of a man who had inborn polio, we have information about how objects be have that these events are naturally impossible (Soskice, 1984). Therefore, nature's law is general and this law expresses what essentially and constantly happen. There upon, if an exception occurs in that, it means that what we know as nature's law was not indeed a law of nature.

With regards to this defect, Swinburne believes that first this reason runs about general laws not statistical laws; second, necessity in nature's law does not mean that it is not exception in order to cause the occurrence of miracle as impossible (Moser, 2010). But these laws and hidden necessity in them do not have exception to repeat in similar conditions. For instance, if an object fly contrary to most of instances in definite conditions like "A", I files in another time in that condition. This exception is not an exception that we consider it as violation of nature's law, but in fact it is expressive of what we presumed as nature's law, it was not in fact a law of nature; but if exception is not repeatable and we cannot have a similar appearance from mentioned law that interpret all event's related to this event, it is in conflict with what we consider as nature's law and does not reject it, since based on mentioned law we can have true predictions in all other conditions except one especial and unrepeatable instance.

\section{CONCLUSION}

This study revealed that the university students believe that both Western and Eastern school of thoughts are worth mentioning in argumentative issues such as miracles to discuss in a cause and effect style of discussion. While the Western scholars are affected by natural laws on justifying the natural facts, the Eastern thinkers also believe that these facts are governed by God rather than just human beings. Thus, the human beings are immediate conductors of the evens happening in the world. The similarities are greater than the differences between the two schools of thoughts.

The advantage of speech is clear where we deal with general laws "canon" since general law says that "those things always do that action", since every reformed rule that gave us the possibility to predict an event. It gives us the possibility to predict similar events in similar conditions and thus we have are liable reason represents false predictions. If we leave the rule without reformation, then we have valid reason on this belief that represents true predictions in other presumed conditions. Just to say that none of the laws forms nature are not efficient in this scope. If we say this, then we should understand the general function law "those things always do those actions that has harmony logically with this statement "this is that thing and it doesn't do that action. Saying that such a special rule is a law is saying that all predictions are true and none of exceptions in his function cannot justify by another rule that perhaps attributed as law. Thus, human beings should distinguish a rule which is law and a rule which is true or a law that is valid and reliable without exception (Beverly \& Clack, 1998).

If as it seems natural, we understand what is naturally impossible and what is rejected by law of nature, then our interpretation from law of nature shows that this assumption that sometimes what realizes which is naturally impossible is meaningful (Plantinga, 1993). This assumption that nature's law has been violated is meaningful deduces that in such a state the "theoretical impossible" occurs. He concludes that since it is in such a way, human cannot deduce from the happened event that this event is possible. Evidence shows what events are violates of nature's law. Results showed that methodology and epistemology of new worldview is required to examine and interpret issues such as miracles according to these methods and the laws of nature. Through comparative linguistics of discussing miracles and the system dominating the nature, the teachers may be able to find solid evidence to know which school of thoughts (i.e., Eastern and Western) can support cause and effect discussions and make class materials more argumentative.

\section{REFERENCES}

[1] Ashtiyani, S. J. 1989. A research in christian religion. Tehran: Negresh Press.

[2] Amedi, S. 2012. Ghayatalmaram fi elm kalam. Translated by Hassan Mahmud Abdollatif. Ghahereh.

[3] Baglow, C. 2005. Rediscovering St. Thomas Aquinas as Biblical theologian. Letter \& Spirit, 1, 137-146. 
[4] Beverly, C and Clack, B. R. 1998. The philosophy of religion: A critical introduction. Oxford: Blackwell.

[5] Dilman, I. 1983. Freud and human nature. New York: Blackwell.

[6] Dilman, I. 1984. Freud and the mind. New York: Blackwell.

[7] Ebrahimi Daniani, G. H 1991. Logic and knowledge in the view of Ghazali. Tehran: Amir Kabir publication Institution.

[8] Hick, J. 1983. Religion philosophy. Translated by Bahram Rad. Tehran: International Hoda Press.

[9] Hume, D. 1969. Natural history. Translated by Hamid Enayat. Tehran

[10] James Pawelski, J. 2007. The dynamic individualism of William James. London: SUNY press.

[11] Javadi Amoli, A. 1991. A commentary of Allameh Tabatabayi. Qum: Ayinehye Mehr. Daral tafsir.

[12] Ibn Khaldoon, M. 1995. Daralkotob Elmiyeh. Beirut.

[13] Ibn Roshd, A. 1992. Alkashf an manahej aladeleh fi aghayed meleh, maa madkhal. Beirut: Center of Arabic Lessons.

[14] Ibn Roshd, A. 1965. Tahafat Altahafat. ( $2^{\text {nd }}$ Vol.). Egypt: Stone Press.

[15] Ibn Sina, H. 1403. Esharat va Tanbihat. (2 ${ }^{\text {nd }}$ Vol.). Tehran: The Office of Publishing Book.

[16] Ibn Arabi, M. 1921. Fosos alhekam. Researched by Abdollah. Afifi. Tehran, Alzahra Press.

[17] Ibn Meimoon, M. 1914. Dalaleh Haerin. Translated by Hossein Atay and Anghreh. Tehran: Bina.

[18] Karnap, R. 1974. A preface on science philosophy(1st Ed.). In Martin Gardner, translated by Yusuf Afifi. Tehran: Niloufar.

[19] Kapelson, F. 1986. Philosophy history. (5 $5^{\text {th }}$ Vol.). Translated by Amir Jalalaldin Aalam. Tehran.

[20] Kovari, J. M 1989. Religious thought in twentieth century (1st Ed.). Translated by Behzad Salegi.Tehran: Amir Kabir press.

[21] Moser, P. 2010. The evidence for God: Religious knowledge reexamined. Cambridge: Cambridge University Press.

[22] Peterson, E. H. and Randall Niles, R. 2007. He great pursuit: The message for those in search of God. New York: NavPress.

[23] Plantinga, A. 1993. Warrant: The current debate. Oxford: Oxford University Press, 1993.

[24] Stiver, D. R. 1996. The philosophy of religious language. Oxford: Blackwell.

[25] Soskice, J. M. 1984. Metaphor and religious language. Oxford: Oxford University Press.

[26] Tabatabei, M. H. 1983. Almizan interpretation in the Holy Quran.(Vol. 1). Tehran: Darolkotob Islamieh.

[27] Tabatabei, M. H. 1985. Almizan interpretation.(Vol. 1). Translated by S. M. B. Hamadani. Qum: Islami Publication.

[28] Tabatabayi, M. H. 1993. Almizan fi Tafsir Qur'an. (1 ${ }^{\text {st }}$ Vol.). Tehran: Daralkotob Eslami.

[29] Tabatabayi, M. H. 1995. Tafsir Almizan. (1 $1^{\text {st }}$ Vol.). Translated by Seyed Mohammad Bagher Mosavi Hamedani. Ghom: Office of Islamic Press.

[30] Tabatabayi, M. H. 1973a. Miracle of Qur'an institution. Ghom:Jamaee Modaresin, Ghom, Islamic Press Institution, Dar Tabligh Eslami.

[31] Tabatabayi, M. H. 1973b. Nahayat Hekmat. Ghom: Jamaee Modaresin, Ghom, Islamic Press Institution, Dar Tabligh Eslami.

[32] Welfson, H. O. 1979. Oration philosophy. Tehran.

[33] Watson, S. 1987. New soul and science. Tehran. 